\title{
Neonatal Administration of Fluoxetine Decreased Final Sertoli Cell Number in Wistar Rats
}

\author{
Administración Neonatal de Fluoxetina Disminuye el Número Final \\ de Células de Sertoli en Ratas Wistar \\ "Valdemiro Amaro da Silva Junior; "Marleyne José Afonso Accioly Lins Amorim; \\ ***Adelmar Afonso de Amorim Junior; ${ }^{* * *}$ Catarina Ferreira Pinto; ${ }^{* * * *}$ Tereza B. J. Deiró;

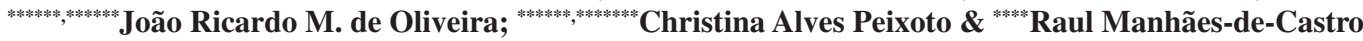

SILVA, J. V. A.; LINS, A. M. J. A. A.; AMORIM, J. A. A.; PINTO, C. F.; DEIRÓ, T. B. J.; OLIVEIRA, J. R. M.; PEIXOTO, C. A. \& MANHÃES-DE-CASTRO, R. Neonatal administration of fluoxetine decreased final sertoli cell number in Wistar rats. Int. J. Morphol., 26(1):51-62, 2008.

SUMMARY: The aim of the present study was to test the hypothesis that the application of fluoxetine - a highly selective serotonin reuptake inhibitor (SSRI) - in rats during the suckling period induces changes in testicular development. Groups of newborn male rats were randomly assigned with different doses of fluoxetine 24 hours after birth. Each litter stayed with its respective mother during 21 days. Body weight (BW) was measured daily from the $1 \mathrm{st}-21^{\text {st }}$ day to calculate daily doses of fluoxetine. $5 \mathrm{mg}$ (T1), 10 mg (T2) $20 \mathrm{mg}$ (T3) or deionized water, were injected intraperitoneally. On the $21^{\text {st }}$ day, animals were heparinized, anesthetized and blood was collected by cardiac puncture to determine by radioimmunoassay the follicle stimulating hormone (FSH) levels. Testis were removed, weighed, and processed for morphometric analysis. Fluoxetine groups presented decreased body and testicular weight when compared with the control group on the $21^{\text {st }}$ day. Our findings show that the manipulation of the serotoninergic system with fluoxetine during the critical period of testicular development alters the Sertoli cell population and all testicular parameters related to this cell.

KEY WORDS: Fluoxetine; Testis development; Sertoli cells; Wistar rats.

\section{INTRODUCTION}

There is a current interest about the repercussions of precocious use of selective serotonin reuptake inhibitors (SSRIs), such as fluoxetine, for the development of various organs and to induce increased serotoninergic activity in the brain (Baumann, 1996; Toornvliet et al., 1996). Experimental evidence indicates that serotonin $(5-\mathrm{HT})$ can influence embryogenesis and growth presumably by acting as a developmental signal or as a neurotrophic factor as well (Liu \& Lauder, 1992; Palén et al., 1979; Whitaker-Azmitia, 1991; Yan et al.,1997; Deiró et al., 2004).

Some studies confirmed that the neonatal use of SSRIs reduce the weight gain during the nursing period in rats followed by a decrease in their depressive-like behavior in the adult life (Deiró et al.; Mendes da Silva et al., 2002). In early-life knockout rodents the blockade of the 5-HT transporter alters emotional behavior in adult mice (Ansorge et al., 2004; Holden, 2004).

Serotonin selective uptake inhibitors are highly lipidsoluble compounds and cross the placenta as well as are excreted to breast milk; however, in humans the relative concentration to a suckling infant for fluoxetine is higher than others SSRIs (Ohman et al., 1999; Spigset et al., 1997). Pharmacological evidence demonstrated also that the elevation of the cerebral levels of 5-HT affects the secretion

* Departamento de Morfologia e Fisiologia Animal, Universidade Federal Rural de Pernambuco, UFRPE, Brasil.

** Departamento de Anatomia, Universidade Federal de Pernambuco, Brasil.

**** Bolsista PIBIC/CNP;

***** Departamento de Nutrição, Universidade Federal de Pernambuco, Brasil.

****** Departamento de Neuropsiquiatria, Universidade Federal de Pernambuco, Brasil.

******* Laboratório de Imunopatologia Keizo Asami (LIKA), Universidade Federal de Pernambuco, Brasil.

********* Departamento de Biologia Celular e Ultraestrutura, Centro de Pesquisas Aggeu Magalhães, Brasil. 
of FSH and luteinizing hormone (LH), for inhibiting the liberation of gonadotrophins releasing factor $(\mathrm{GnRH})$ in the hypothalamus, with subsequent effects on the process of spermatogenesis and steroidogenesis in adult rats (Das et al., 1982, 1985; Naumenko \& Shishkina, 1978; Urry \& Dougherty, 1975). In newborn rats, adequate levels of FSH are crucial for the growth of Sertoli cell population, which is directly related to testicular size and sperm production (França et al., 2000). Serotonin is present in the testis and accessories glands, besides many organic tissues. In these glands, monoaminoxidase, the enzyme that metabolizes 5HT, is also detected (Aguilar et al., 1995; Campos et al., 1990; Ellis et al., 1972; Tinajero et al., 1993; Sanders-Bush \& Mayer, 2001; Verbeuren, 1989). In rats, the testicular 5HT can originate from the nerve endings in the capsule, the mast cells and the Leydig cells (Campos et al.; Kops et al., 1990; Tinajero et al.). In hamsters, the periods of sexual development and the transition between testicular regression and recrudescence are related to changes in the 5-HT levels in the mast cells and Leydig cells (Frungieri et al., 1999). In the testis, the 5-HT can reduce the steroidogenesis and the spermatogenesis by decreasing the intratesticular flow due to arterial constriction or inhibiting fundamental enzymes of the steroidogenesis (Kalla, 1979; Das et al., 1982, 1985, 1986; Hedger et al., 1995). This suggests that this neurotransmitter can act as an important local modulator on the steroidogenesis and spermatogenesis.

In spite of vast knowledge about the action of the biogenic amines in the control of the reproductive functions, at present, there is no information on the pharmacological manipulation of the serotoninergic system, during the critical period of the testicular development in newborns rats (Das et al., 1982, 1985; Balon, 1995; Hedger et al., 1995; Labbate et al., 1998; Vega Matuszcyk et al., 1998; Waldinger \& Olivier, 1998; Cantor et al., 1999). Therefore, the objective of the present study is to investigate the testicular development of newborn rats after treatment with fluoxetine, a highly selective serotonin reuptake inhibitor.

\section{MATERIAL AND METHOD}

This project was submitted to the Animal Ethics Committee of the Federal Rural University of Pernambuco. Animals, pharmacological manipulations and experimental design.

Newborn Wistar rats (Rattus norvegicus, var. albinus) were randomly chosen to compose the following groups: the control group (6 rats); the T1 group, treated with $5 \mathrm{mg}$ / $\mathrm{Kg}$ of fluoxetine chloride (6 rats); the T2 group treated with
$10 \mathrm{mg} / \mathrm{Kg}$ of fluoxetine chloride (6 rats); and the T3 group, treated with $20 \mathrm{mg} / \mathrm{Kg}$ of fluoxetine chloride (6 rats). The animals in the experimental groups stayed with their mothers in individual cages, for 21 days, in a 12-h light-dark cycle, with controlled humidity and temperature.

The treated groups were given daily intraperitoneal injections of fluoxetine chloride according to body weight as described elsewhere (Gandarias et al., 1999; Nowakowska et al., 1997; Vega Matuszcyk et al.; Frank et al., 2000). During the same period of time, the control group was given sterilized deionized water, used as the diluent of fluoxetine chloride solution. The treatment began on day one of life and continued through day 21 .

Data Collection and Samples. The animals were weighted daily during the 21 days of the experiment, to record the growth curve of body weight and to calculate the dosage of fluoxetine chloride. At the end of the experiment, the rats were heparinized (125UI/100g) and anesthetized with a solution of $2 \%$ sodium thiopental $(0,25 \mathrm{ml} / 100 \mathrm{~g})$, by intraperitoneal injection. After deep sedation, samples of blood were collected by cardiac puncture, the serum removed and stored at $-20^{\circ} \mathrm{C}$. The testis were removed, weighed, cut into tissue fragments $2 \mathrm{~mm}$ thick and preserved in $2.5 \%$ glutaraldehyde, in a $0.01 \mathrm{M}$ pH 7.4 sodium phosphate buffer, for two hours, at $5^{\circ} \mathrm{C}$.

The fragments were routinely processed for embedding in glicol metacrilato. Fragments with a thickness of $4 \mu \mathrm{m}$ were routinely stained with toluidine blue for histological analysis.

Testis Morphometry. The volume density of the components of the parenchyma was estimated at 8820 points per animal, using a micrometric reticule square with 441 point (Olympus) coupled to an ocular with $10 \mathrm{X}$ magnification and a objective with 40X magnification (400X final magnification). The counts were performed using a BX51 Olympus optical microscope. The volume of each testicular component, expressed in $\mathrm{mL}$, was estimated based on knowledge of the percent of volume occupied by each of these components and by the net weight of the testis, which was obtained by subtracting the tunica albugínea weight; and since the testicular density is known to be approximately 1.0 , the weight of the testis was considered to be equal to its volume (França \& Cardoso, 1998; França \& Russel, 1998). The average diameter of 30 cross sections of round sex cord/ seminiferous tubule per animal, was obtained utilizing a linear reticule micrometer (U-OCMSQ10/10, Olympus) coupled to an ocular with $10 \mathrm{X}$ magnification and a objective with $10 \mathrm{X}$ magnification (100X final magnification). In the same cross sections used to measure the tubular diameter, 
the height of the seminiferous epithelium was taken from the membrane base to the tubular lumen. The height of the epithelium in each tubule represents the average of the diametrically opposite measurements. The counts were performed using a BX51 Olympus optical microscope using a digital hemocytometric cell counter (Leucotron T-P).

The total length of seminiferous tubules (LST) per testis, expressed in meters, was estimated based on the tubules seminiferous volume (TSV) in the testis and the average area of tubules obtained from each animal, according to the following formula: $\mathrm{LST}=\mathrm{TSV} / \pi \mathrm{R}^{2}$ (Attal \& Courot, 1963; Dorst e Sajonski, 1974).

Cell counting. The estimate of the different types of cells that compose the epithelial seminiferous tubule, was made by counting the nuclei of the germ cells and the nuclei of the Sertoli cells. A minimum of 10 cross sections of sex cords/ seminiferous tubules were measured in each sample. The following types of nuclei were found: spermatogonia A, spermatogonia B, spermatocytes I and Sertoli cells. To measure nuclear diameter average of Sertoli and spermatogonia A cells the following formula was applied:

$$
\text { Medium diameter }=\frac{\text { length diameter }+ \text { width diameter }}{2}
$$

The counts obtained were corrected according to the nuclear diameter (ND) and the thickness of the histological fragments following the formula:

Corrected number $=$ counting $X$ width section/width section $+\sqrt{(\mathrm{ND} / 2)^{2}-(\mathrm{ND} / 4)^{2}}$ (Abercrombie, 1946; Amann \& Almquist, 1962).

The number of germ cells and Sertoli cells was obtained from the corrected number of these cells per cross section of the sex cord/seminiferous tubules and the total of sex cord/ seminiferous tubules per testis (Hochereu De Reviers \& Lincoln, 1978), according to the following formula:

Number of Sertoli or germ cells per testis $=$ Seminiferous tubules total length $(\mathrm{mm}) \mathbf{X}$ corrected number of Sertoli cell per cross section/section width $(\mu \mathrm{m})$.
FSH plasma levels. The FSH plasma levels were obtained by means of radioimmunoassays (RIAs) in the solid phase, using commercial kits provided by Diagnostic Systems Laboratories (Webster, Texas, USA). After determining the standard curve of the control group, an aliquot of $100 \mu \mathrm{L}$ of blood serum was placed in each duplicate test tube and solution to which $100 \mathrm{~mL}$ anti-FSH (I-125) reagent was added.

This mixture was agitated for 2 seconds and incubated at $37^{\circ} \mathrm{C}$, for 60 minutes. After this step, the tubes were decanted. Radioactivity was measured by a gamma counter attached to a computer, and the final calculation was expressed in $\mathrm{mIU} / \mathrm{mL}$ of plasma for FSH. The standard curve was established with doses of FSH varying from 0.0 to $450 \mathrm{mIU} / \mathrm{mL}$.

Statistical analysis. The biometric, histometric and hormonal data were expressed as mean \pm standard deviation. These results were submitted to variance analysis (ANOVA), and the Tukey test was performed between groups. The significance level adopted in the statistical tests was $\mathrm{P}<0.05$.

\section{RESULTS}

Morphometric date. At the end of the experiment, the animals treated with different doses of fluoxetine chloride showed a reduction in body and testis weight in comparison with the control group (Table I). However, the gonadosomatic index, which characterizes the percent of body mass located in the testis, did not show any differences among the treated groups (Table I). According to the development curve recorded during the 21 day-period after birth, the animals in the treated groups showed a reduction of body weight during the period of treatment compared to the animals in the control group (Fig. 1).

Table II shows volume data of testis (net weight), seminiferous tubule, seminiferous epithelium, lumen, tunica propria, lymphatic space, Leydig cell and blood vessels of the experimental and control groups.

Table I. Biometric parameters of the Wistar rat control group and groups treated with different doses of fluoxetine from birth to the $21^{\text {st }}$ day post-natal. Values are the mean \pm SEM; six animals per group. Different letters above the bars denote a statistically significant difference between groups $(\mathrm{P}<0.05)$

\begin{tabular}{|c|c|c|c|c|}
\hline \multirow[b]{2}{*}{ Parameters } & \multicolumn{4}{|c|}{ Experimental groups } \\
\hline & $\begin{array}{l}\text { Control } \\
(n=6)\end{array}$ & $\begin{array}{c}\text { T1 } \\
(5 \mathrm{mg} / \mathrm{kg}) \\
(\mathrm{n}=6)\end{array}$ & $\begin{array}{c}\text { T2 (10mg/kg) } \\
(\mathrm{n}=6)\end{array}$ & $\begin{array}{c}\text { T3 }(20 \mathrm{mg} / \mathrm{kg}) \\
(\mathrm{n}=6)\end{array}$ \\
\hline Body weight (g) & $53.5 \pm 4.37 \mathrm{a}$ & $43.9 \pm 6.05 b$ & $39.8 \pm 3.56 b$ & $40.2 \pm 4.64 b$ \\
\hline Testicular weight (g) & $0.140 \pm 0.01 \mathrm{a}$ & $0.100 \pm 0.01 b$ & $0.101 \pm 0.01 b$ & $0.094 \pm 0.01 b$ \\
\hline Gonadosomatic index & $0.26 \pm 0.03$ & $0.23 \pm 0.03$ & $0.27 \pm 0.05$ & $0.23 \pm 0.02$ \\
\hline
\end{tabular}




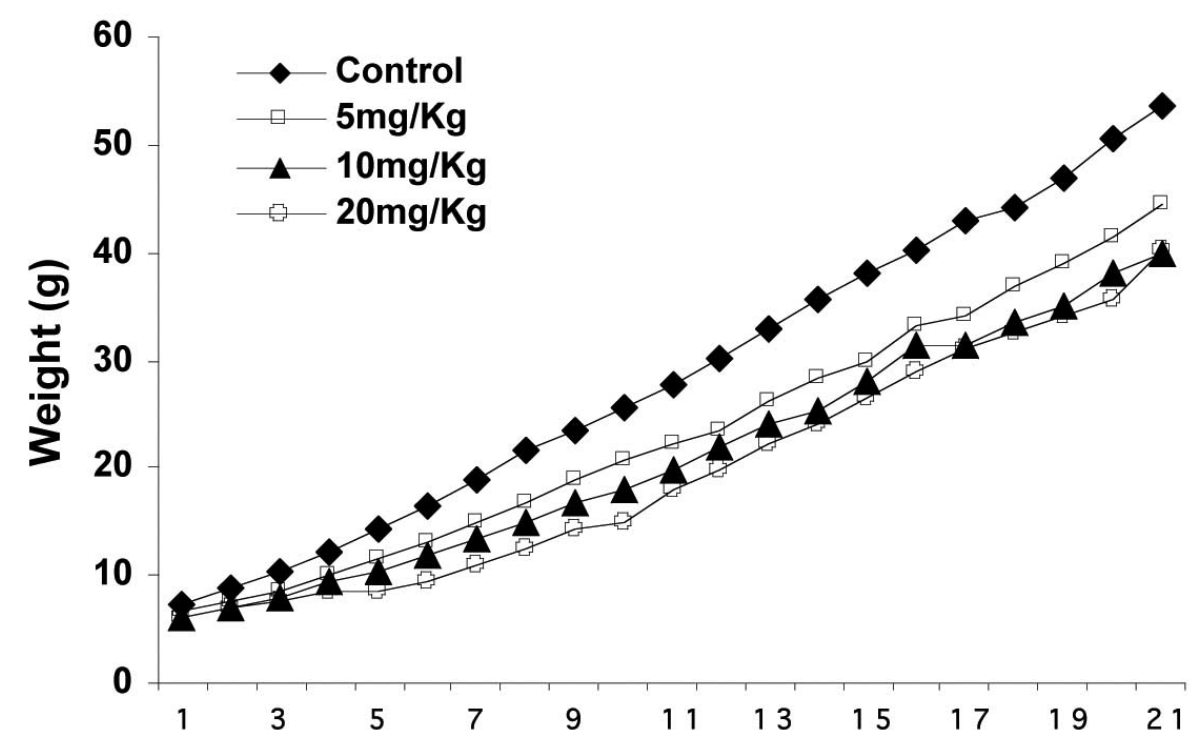

Fig. 1. Body weight from the $1^{\text {st }}$ to $21^{\text {st }}$ day of life of suckling rats in the control group and groups treated with and groups treated with $5 \mathrm{mg} / \mathrm{Kg}$ (T1), $10 \mathrm{mg} / \mathrm{Kg}$ (T2) and $20 \mathrm{mg} / \mathrm{Kg}$ (T3) of fluoxetine recorded on the $21^{\text {st }}$ day post-natal of fluoxetine during the experimental period.

Biometric parameters of the testis such as net weight of the testis, volume of the sex cords/seminiferous tubule, seminiferous epithelium and total length of seminiferous tubules showed a reduction in the groups treated with fluoxetine compared to the control group animals. Conversely, the lumen of seminiferous tubule volume was reduced only in the group treated with the highest dose of fluoxetine chloride. The volume of the testicular parenchyma allocated in tunica propria was lower in rats treated with 5 and $10 \mathrm{mg} / \mathrm{Kg}$ of fluoxetine, but this reduction in volume was not significant among those treated with the highest dose of antidepressant. The total volume of Leydig cells showed no significant differences between the experimental and control groups. However, between animals treated with the greatest dosages (10 and $20 \mathrm{mg} / \mathrm{Kg})$ there is a difference significant in the Leydig cell volume. The other volume parameters analyzed showed similarities among the groups.

Table II. Volume of testis components $(\mathrm{mL})$ of the Wistar rat control group and groups treated with different doses of fluoxetine from birth to the $21^{\text {st }}$ day post-natal. Values are the mean \pm SEM; six animals per group. Different letters above the bars denote a statistically significant difference between groups $(\mathrm{P}<0.05)) .1$ Exclude $9.2 \%$ of testis capsule.

Experimental groups

$\begin{array}{lcccc}\text { Parameters } & \begin{array}{c}\text { Control } \\ (\mathbf{n = 6})\end{array} & \begin{array}{c}\text { T1 (5mg/kg) } \\ (\mathbf{n = 6})\end{array} & \begin{array}{c}\text { T2 (10mg/kg) } \\ (\mathbf{n}=\mathbf{6})\end{array} & \begin{array}{c}\text { T3 }(\mathbf{2 0 m g} / \mathbf{k g}) \\ (\mathbf{n = 6})\end{array} \\ \text { Testis volume }^{1} & 126.7 \pm 10.0 \mathrm{a} & 90.7 \pm 9.3 \mathrm{~b} & 91.8 \pm 13.5 \mathrm{~b} & 85.0 \pm 9.5 \mathrm{~b} \\ \text { Seminiferous tubule volume } & 109.5 \pm 3.8 \mathrm{a} & 72.5 \pm 2.7 \mathrm{~b} & 74.8 \pm 2.0 \mathrm{~b} & 69.6 \pm 10.3 \mathrm{~b} \\ \text { Seminiferous epithelium } & 95.4 \pm 5.3 \mathrm{a} & 64.9 \pm 2.8 \mathrm{~b} & 66.9 \pm 0.7 \mathrm{~b} & 58.5 \pm 17.9 \mathrm{~b} \\ \text { Lumen } & 9.2 \pm 5.9 \mathrm{a} & 4.6 \pm 2.2 \mathrm{ab} & 4.3 \pm 2.0 \mathrm{ab} & 7.0 \pm 7.0 \mathrm{~b} \\ \text { Tunica propria } & 4.9 \pm 1.0 \mathrm{a} & 3.0 \pm 0.5 \mathrm{~b} & 3.6 \pm 1.0 \mathrm{bc} & 4.4 \pm 0.8 \mathrm{ac} \\ \text { Leydig cell } & 3.0 \pm 0.8 \mathrm{ab} & 2.4 \pm 0.5 \mathrm{ac} & 2.1 \pm 0.3 \mathrm{a} & 3.4 \pm 1.3 \mathrm{bc} \\ \text { Connective cells } & 1.2 \pm 0.4 \mathrm{a} & 0.8 \pm 0.2 \mathrm{a} & 0.7 \pm 0.4 \mathrm{a} & 1.1 \pm 0.5 \mathrm{a} \\ \text { Blood vessel } & 2.3 \pm 1.3 \mathrm{a} & 2.3 \pm 0.9 \mathrm{a} & 1.2 \pm 0.4 \mathrm{a} & 2.6 \pm 3.6 \mathrm{a} \\ \text { Lymphatic space } & 14.0 \pm 3.0 \mathrm{a} & 12.0 \pm 3.0 \mathrm{a} & 11.2 \pm 1.8 \mathrm{a} & 11.5 \pm 2.3 \mathrm{a}\end{array}$


In regard to the cell population of sex cord/ seminiferous tubule per cross sections, there was a decrease in the number of Sertoli cells, only among animals treated with $10 \mathrm{mg} / \mathrm{Kg}$ of fluoxetine, compared to those treated with $5 \mathrm{mg} / \mathrm{Kg}$. A reduction of $24 \%, 40 \%$, and $44 \%$ in the number of spermatogonia A was observed in cross sections of the sex cords/seminiferous tubules in animals treated with 5,
10 , and $20 \mathrm{mg} / \mathrm{Kg}$ of fluoxetine, respectively (Table III). The number of spermatogonia B cells showed no differences between the experimental and control groups. However, there was a gradual reduction (6-12\%) in the number of these cells observed in cross sections of groups treated with 10 and $20 \mathrm{mg} / \mathrm{Kg}$ of fluoxetine, when compared to group that received $5 \mathrm{mg} / \mathrm{Kg}$ of fluoxetine (Table III).

Table III. Cell populations per cross section of the sex cords/seminiferous tubule of the Wistar rats in the control group and groups treated with different doses of fluoxetine on the $21^{\text {st }}$ day post-natal. Values are the mean \pm SEM; six animals per group. Different letters above the bars denote a statistically significant difference between groups $(\mathrm{P}<0.05)$.

\section{Experimental groups}

\begin{tabular}{lcccc} 
Param eters & Control $(\mathbf{n}=\mathbf{6})$ & $\mathbf{T 1}(\mathbf{5 m g} / \mathbf{k g})(\mathbf{n}=\mathbf{6})$ & $\mathbf{T 2}(\mathbf{1 0 m g} / \mathbf{k g})(\mathbf{n}=\mathbf{6})$ & $\mathbf{T 3}(\mathbf{2 0 m g} / \mathbf{k g})(\mathbf{n}=\mathbf{6})$ \\
\hline Spermatogonia A & $1.77 \pm 0.67 \mathrm{a}$ & $1.35 \pm 0.20 \mathrm{ab}$ & $1.07 \pm 0.15 \mathrm{~b}$ & $1.0 \pm 0.2 \mathrm{~b}$ \\
Spermatogonia B & $31.77 \pm 2.83 \mathrm{ab}$ & $34.81 \pm 3.81 \mathrm{a}$ & $29.72 \pm 2.85 \mathrm{~b}$ & $27.72 \pm 2.0 \mathrm{~b}$ \\
Sertoli cell & $20.58 \pm 1.16 \mathrm{abc}$ & $21.46 \pm 2.33 \mathrm{~b}$ & $18.20 \pm 1.64 \mathrm{c}$ & $20.52 \pm 2.0 \mathrm{abc}$ \\
Spermatocytes I & $9.73 \pm 2.62$ & $14.86 \pm 8.59$ & $11.15 \pm 2.41$ & $14.42 \pm 5.2$
\end{tabular}

The structure of testis parenchyma in experimental and control groups are shown at the Fig. 2. The control group present a more defined tubular lumen of seminiferous tubules after 21 days, when compared to the treated group, confirming the results of lumen volume $(\mu \mathrm{L})$ obtained. The diameters of the sex cords/seminiferous tubules were not affected by manipulation of the neonate's serotoninergic system using fluoxetine (Table IV). In regard to biometric parameters, there was a significant reduction in the total length of the seminiferous tubule among the animals treated with varying doses of fluoxetine (Table IV). The treated groups presented an impressive decrease in total number of Sertoli cells per testis (Table IV). In addition, the population of spermatogonia A per testis was reduced significantly directly proportional to the dose given (Table IV). Similarly, the numbers of spermatogonia B among treated animals showed the same tendency previously described for the spermatogonia A population, showing a more drastic reduction (40\%) in animals treated with $20 \mathrm{mg} / \mathrm{Kg}$, whereas groups treated with 5 and $10 \mathrm{mg} / \mathrm{Kg}$ showed reductions of only 21 and $27 \%$, respectively (Table IV). On the other hand, no alterations were observed in the spermatocytes I of the experimental groups when compared to the control ones.

FSH plasma levels. The serum levels of FSH were lower in animals treated with fluoxetine, though only groups treated with 5 and $10 \mathrm{mg} / \mathrm{Kg}$ of fluoxetine showed significant reduction compared to the control group (Fig. 3).

Table IV. Biometric parameters and cell population of testis of the Wistar rats in the control group and groups treated with different doses of fluoxetine recorded on the 21 st day post-natal. Values are the mean \pm SEM; six animals per group. Different letters above the bars denote a statistically significant difference between groups $(\mathrm{P}<0.05)$.

Parameters

Seminiferous tubule diameter $(\mu \mathrm{m})$

Epithelium height $(\mu \mathrm{m})$

Sertoli cells/cross section of seminiferous tubule

Sertoli cells /testicle $\left(\mathbf{x 1 0}^{7}\right)$

Spermatogonia A / testicle $\left(\mathrm{x10}^{6}\right)$

Spermatogonia B / testicle $\left(\mathrm{x}^{10} 0^{6}\right)$

Spermatocytes I / testicle $\left(\mathrm{x}^{6}{ }^{6}\right)$

Total length of seminiferous tubule (m)

Control (n=6)
$149.2 \pm 8.0$
$54.1 \pm 6.6$
$20.58 \pm 1.16 \mathrm{ac}$
$3.13 \pm 0.21 \mathrm{a}$
$2.78 \pm 1.20 \mathrm{a}$
$48.67 \pm 6.25 \mathrm{a}$
$15.06 \pm 5.10$
$6.12 \pm 0.50 \mathrm{a}$

\section{Experimental groups}

$\begin{array}{ccc}\mathbf{T 1}(\mathbf{5 m g} / \mathbf{k g})(\mathbf{n}=\mathbf{6}) & \mathbf{T 2}(\mathbf{1 0 m g} / \mathbf{k g})(\mathbf{n}=\mathbf{6}) & \mathbf{T 3}(\mathbf{2 0} \mathbf{m g} / \mathbf{k g})(\mathbf{n = 6}) \\ 145.8 \pm 3.0 & 143.5 \pm 11.4 & 141.3 \pm 7.1 \\ 50.3 \pm 6.3 & 46.0 \pm 6.4 & 51.3 \pm 7.3 \\ 21.47 \pm 2.33 \mathrm{ab} & 18.20 \pm 1.64 \mathrm{c} & 20.50 \pm 2.00 \mathrm{ac} \\ 2.32 \pm 0.13 \mathrm{~b} & 2.13 \pm 0.27 \mathrm{~b} & 2.12 \pm 0.19 \mathrm{~b} \\ 1.52 \pm 0.32 \mathrm{~b} & 1.27 \pm 0.14 \mathrm{~b} & 1.0 \pm 0.12 \mathrm{~b} \\ 38.33 \pm 7.10 \mathrm{~b} & 35.10 \pm 5.25 \mathrm{bc} & 28.83 \pm 3.13 \mathrm{c} \\ 15.83 \pm 9.0 & 13.00 \pm 2.53 & 14.83 \pm 5.15 \\ 4.37 \pm 0.39 \mathrm{~b} & 4.74 \pm 0.65 \mathrm{~b} & 4.20 \pm 0.52 \mathrm{~b}\end{array}$




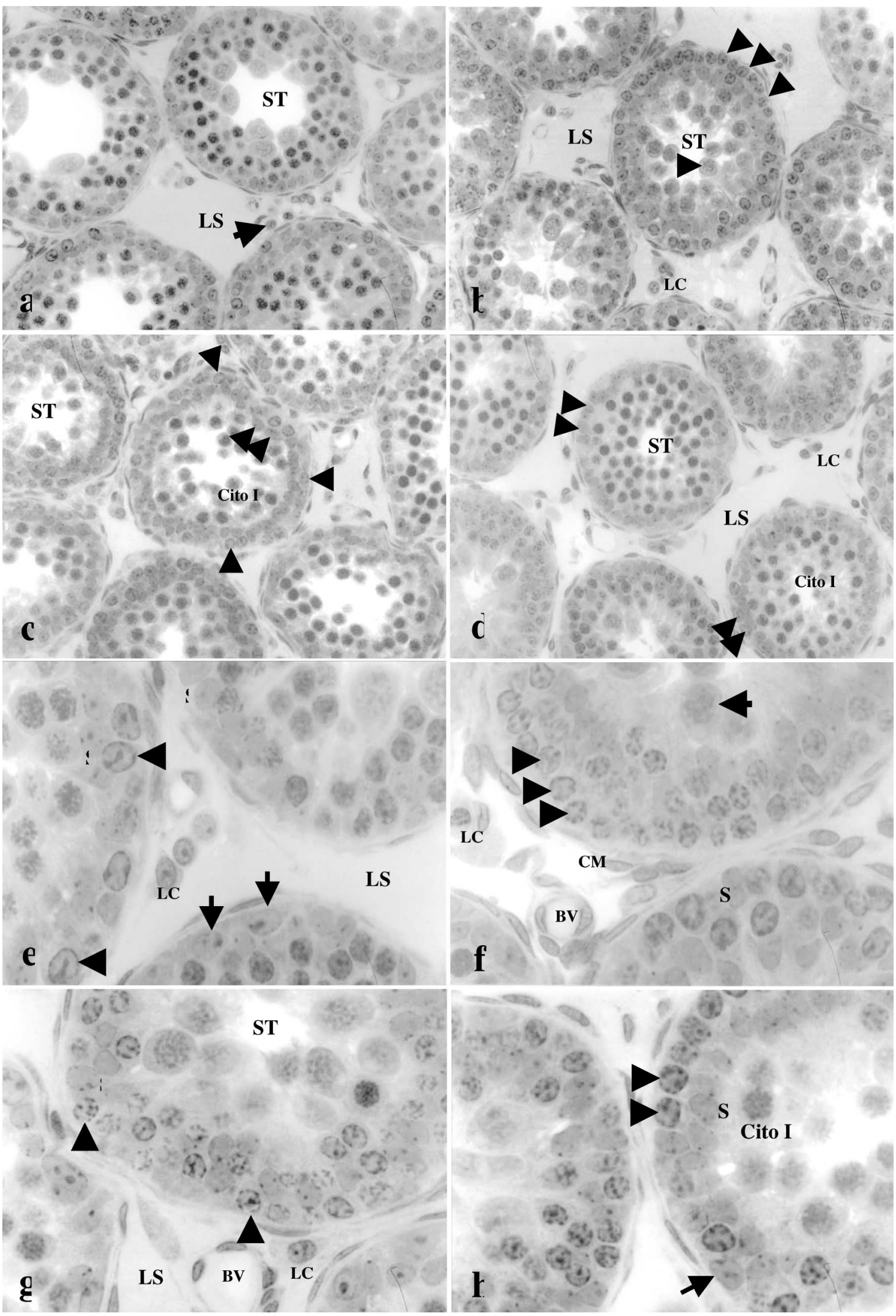


Fig. 2. Testis parenchyma of control Wistar rats and groups treated with various doses of fluoxetine during the $20^{\text {th }}$ first post natal days. Fig. 2a. Control group. Seminiferous tubules on a transversal slice (TS) presenting define lumen, lymphatic space (LS) and Leydig cells clusters (arrow) closer to seminiferous tubules.

Fig. 2b. Fluoxetine $5 \mathrm{mg} / \mathrm{Kg}$ - Seminiferous tubules (ST) showing reduced lumen. Note B spermatogonia (arrow), closer to tunica propria, and spermatocytes I limited by lumen (arrow). Lymphatic space (LS); Leydig cells (LC).

Fig. 2c. Fluoxetine $10 \mathrm{mg} / \mathrm{Kg}-\mathrm{A}$ reduction of the luminal space of seminiferous tubules (ST) is evident. Observe B spermatogonia (arrowheads), and Sertoli cells (arrows) limited by B spermatogonia and spermatocytes I (cito I).

Fig. 2d. Fluoxetine $20 \mathrm{mg} / \mathrm{Kg}$ - Seminiferous tubules (ST) with a striking lumen reduction. Observe several Sertoli cells (arrow) lined at the base of the germinative epithelium. Spermatocytes I at the lumen of Seminiferous tubules (cito I). Note seminiferous tubules at the inferior corner of the figure with similar cell arraysat presented at figure C. Spermatogonia B (arrowheads); Sertoli cells (S); Spermatocyte I (arrow); Lymphatic space (LS); Leydig cells (LC).

Fig. 2e. Control group - Detail of the seminiferous epithelium. Spermatogonia A (arrows); Spermatogonia B (arrowheads); Sertoli cell (S); Lymphatic space (LS); Leydig cells (LC).

Fig. 2f. Fluoxetine $5 \mathrm{mg} / \mathrm{Kg}$ - Spermatogonias B at the basal compartment of germinative epithelium (arrowheads). Sertoli cells (S); Spermatocytes I (arrow). Intertubule with blood vessels (BV), Leydig cells (LC). Mioid cells (CM).

Fig. $2 \mathrm{~g}$. Fluoxetine $10 \mathrm{mg} / \mathrm{Kg}$ - Detail of the seminiferous tubules (ST) and intertubular space. Sertoli cells (S); spermatogonia B (arrowheads); blood vessels (BV); Leydig cells; Lymphatic space (LS).

Fig. 2h. Fluoxetine $20 \mathrm{mg} / \mathrm{Kg}$ - Observe the presence of Sertoli cells at the germinative epithelium (S), spermatogonia A (arrow) and B (arrowheads). Note tubular lumen closer to primary spermatocytes (cito I).

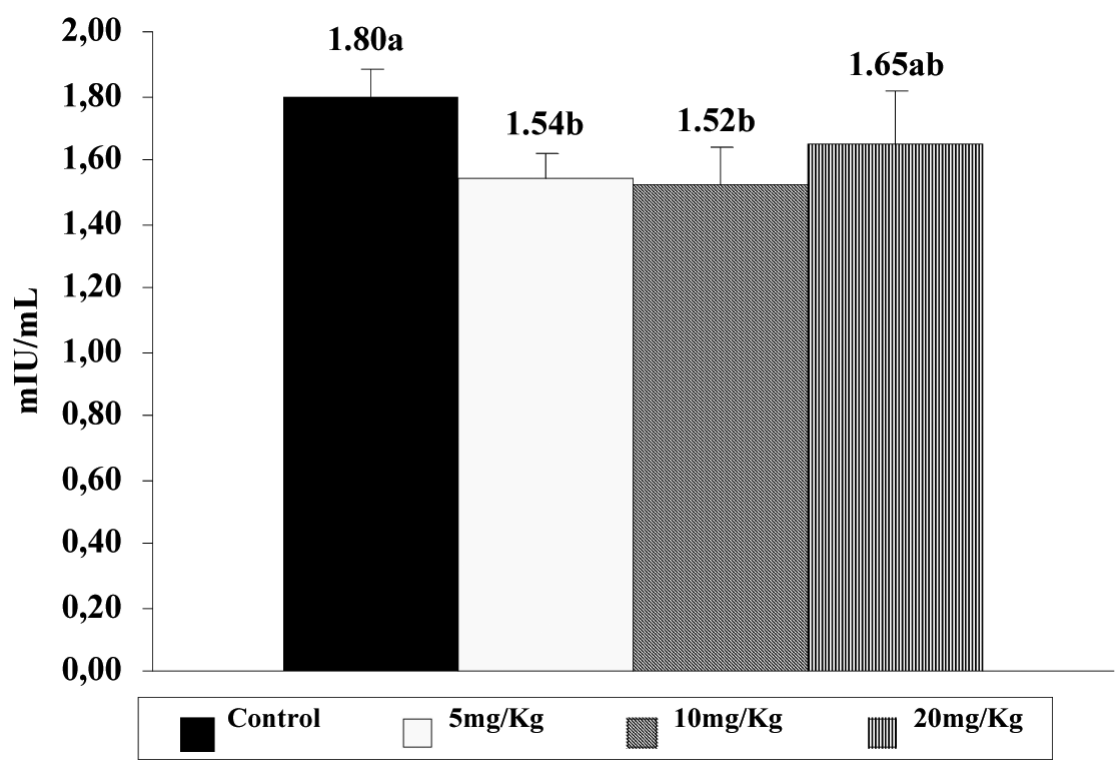

Fig. 3. FSH levels $(\mathrm{mIU} / \mathrm{mL})$ of rats in the control group and groups treated with $5 \mathrm{mg} / \mathrm{Kg}(\mathrm{T} 1), 10 \mathrm{mg} /$ $\mathrm{Kg}$ (T2) and $20 \mathrm{mg} / \mathrm{Kg}$ (T3) of fluoxetine recorded on the $21^{\text {st }}$ day post-natal. Values are the mean \pm SEM; six animals per group. Different letters above the bars denote a statistically significant difference between the groups $(\mathrm{P}<0.05)$.

\section{DISCUSSION}

The present study demonstrated that chronic administration of fluoxetine reduces the body weight and presents harmful effects to the testicular development.

Previous studies showed that the use of citalopram and fluoxetine, administered subcutaneously during the first 21 postnatal days induced reduction of weight gain curve in rats (Deiró et al.; Mendes da Silva et al.). This effect can be attributed to the inhibitory action of the serotonin on the alimentary ingestion (Simansky, 1996). These SSRIs seem to increase availability of the serotonin in the synaptic cleft in level of SNC, which would explain the reducer effect of hunger and alimentary ingestion in humans and the hypophagia in rats (Macguirk \& Siloverstone, 1990; Nowakowska et al.; Wong et al., 1988). Furthermore, there is also reduction in the height of the intestinal villosity caused by the neonatal administration of SSRI. (Morrison et al., 2005). Thus, the reduction weight gain curve can also be 
related to decrease of intestinal absorption, provoking a reduction of essential nutrients.

On the other hand, according to Morrison et al., the prenatal use of fluoxetine in sheep causes acute increase of plasmatic 5-HT levels, reducing uterine blood flow and then decreasing the availability of oxygen and nutrients, inducing growth reduction and/or premature delivery. However, is important to highlight that our study used fluoxetine administration during the post-natal period in rats, which development of the CNS, autonomous system as well as the testis development is more evident during the suckling period.

In human fluoxetine and its active metabolite, norfluoxetine, show long elimination half-lives (1-3 days and 7-15 days, respectively), suggesting risks for accumulation into breast milk affecting especially infants. Studies of pharmacokinetics of fluoxetine and norfluoxetine in pregnancy and lactation demonstrated high concentrations of these substances during the early postnatal period, which decline gradually during the first 2 months of life (Heikkinen et al., 2003). On the other hand, in rats the oral administration of 5-20 mg/Kg of fluoxetine and norfluoxetine presented a mean elimination of half-lives of 5 and 15 hours, respectively (Caccia et al., 1990). Although the clearance of these compounds is higher in rodents than humans, in the present study we utilized the same dose of fluoxetine as described elsewhere (Nowakowska et al.; Matuszcyk et al.; Gandarias et al.; Frank et al.).

The testicular weight of the treated animals had an average reduction of $32.5 \%$ when compared to the control group; however, the most pronounced effect (36\%) was observed in the group treated with $20 \mathrm{mg} / \mathrm{Kg}$. In this experiment, a reduction between 30 and $32 \%$ in the number of Sertoli cells per testis was observed in the animals treated with SSRI; which justifies the reduction of the testicular weight in the same magnitude. Biometric parameters, such as volume of the testis, volume of sex cords/seminiferous tubule, seminiferous epithelium and total length of seminiferous tubules that possess a direct correlation with the number of Sertoli cells (França \& Russel) had an average reduction of $30 \%$ in the animals treated with fluoxetine during the critical period of the testicular development.

The testis presents fast growth during the fetal and neonatal period; however each cellular population expands in different phases influenced by different intra and extra testicular factors. In rats, these periods are of great importance for the establishment of the final size of the testis and of the spermatic production in adult animals (Orth, 1993). The fetal period between the $18^{\text {th }}$ and $21^{\text {th }}$ day of gestation corresponds to the period of larger expansion of the population of Sertoli cells. This expansion gradually decreases during the postnatal period until it ceases completely between the $10^{\text {th }}$ and the $16^{\text {th }}$ day when a population of $30.0 \pm 2.5$ million Sertoli cells per testis has been established (Orth, 1982; Zhengwei et al., 1990). In this phase of the testicular development, the Sertoli cells influence the weight of the testis directly; therefore, any hormonal imbalance or pharmacological interference can modify the spermatogenic activity in the adult (Hess et al., 1993; ; Van Haaster et al., 1993; Cooke, 1995; França, 1995). The neonatal manipulation of the serotoninergic system, by fluoxetine, caused retardation in testicular development that can be characterized by the reduction of the populations of Sertoli cells, spermatogonias A and B, as well as other biometric parameters already mentioned previously. These effects can be due to the elevation of the serotonin levels in consequence of the selective inhibition of its reuptake (Bansal-Rajbanshi \& Mathur, 1985). Local application of serotonin (5-HT) or fluoxetine in the nuclei accumbens and arcuato promotes local liberation of b-endorphin, demonstrating that the mechanism of action of SSRI and tricyclic antidepressants involves the serotoninergic modulation of the system of endogenous opioids (Zagen et al., 2002). It is probable that the elevation of the serotonin levels in the neonates might have altered the levels of opioid peptides, mainly the one of b-endorphin in the hypothalamus (Gilmore, 1995).

The FSH levels had an average reduction of $15 \%$ in the groups T1 and T2 when compared to the control group (Fig. 2). In the group T3, larger reduction of these serum levels was expected, however only a slight reduction was verified (8\%). FSH is considered the principal mitogenic factor responsible for the proliferation of the Sertoli cells; however, other factors can modulate the proliferation of these cells (França et al.). This modulation can be made by the serotonin produced by the Leydig cells (autocrine action), and/or other sources, including interstitial mast cells, systemic sources, or nervous fibers in physiologic and pathological states (Dufau et al., 1993). In this study, it likely that the increase of the serotonin levels provoked by the treatment with SSRI inhibited the proliferation of the Sertoli cells. The activation of 5HT2 receptors in the Leydig cells by serotonin provokes a cascade of autocrine events that promote the intratesticular increase of corticotrophin releasing hormone $(\mathrm{CRH})$ and b-endorphin (Dufau et al.). The latter, act as paracrine modulator of the proliferative response of the Sertoli cells to FSH through the inhibition of the connection of the FSH receptor with the adenylate cyclase (Morris et al., 1987; Orth, 1986; Orth \& Boehm, 1990). In addition, it is probable that serotonin acts directly in the modulation of the proliferation of the Sertoli cells, 
due to the fact that receptors were detected in these cells and an increase in the mRNA expression was observed for these receptors, in presence of this biogenic amine or agonists of these serotoninergic receptors (Syed et al., 1999; Syed \& Hecht, 2001). On the other hand, the reduction of the population of Sertoli cells, spermatogonias A and B, could be a consequence of malnutrition caused by factors already mentioned during the suckling period. In this condition, depression occurs in the synthesis of the DNA of spermatogonia and Sertoli cells (Bansal-Rajbanshi \&
Mathur). In this experiment, the treatment with fluoxetine, a drug commonly used in antidepressant therapies, interfered in testicular maturation. The main consequence of the use of antidepressant therapies during the critical period of testicular development is that, due to the reduction of the population of Sertoli cells, reduction of the spermatic production in adult individuals becomes probable because the number of Sertoli cells established during the prepubertal period determines the final testis size and the number of sperm produced in the sexually mature animal (Frank et al.).

SILVA, J. V. A.; LINS, A. M. J. A. A.; AMORIM, J. A. A.; PINTO, C. F.; DEIRÓ, T. B. J.; OLIVEIRA, J. R. M.; PEIXOTO, C. A. \& MANHÃES-DE-CASTRO, R. Administración neonatal de fluoxetina disminuye el número final de células de sertoli en ratas Wistar. Int. J. Morphol., 26(1):51-62, 2008.

RESUMEN: La propósito del presente estudio fue probar la hipótesis que el uso de fluoxetina - un inhibidor altamente selectivo de la serotonina (SSRI) - induce cambios en el desarrollo testicular de ratas durante el período de amamantamiento. Los grupos de ratas macho recién nacidas fueron asignados aleatoriamente con diversas dosis del fluoxetina, 24 horas después del nacimiento. Cada cría permanecía con su madre respectiva durante 21 días. El peso corporal (BW) fue medido diariamente desde el 21 día 1 al 21 , para calcular la dosis diarias del fluoxetina. $5 \mathrm{mg}$ (T1), $10 \mathrm{mg}$ (T2) y 20 (T3) o agua desionizada fueron inyectados intraperitonealmente. En el día 21, los animales fueron tratados con heparina, anestesiados y la sangre fue recogida por punción cardiaca para determinar por radioinmunoanálisis los niveles de la hormona folículo-estimulante (FSH). Los testículos fueron retirados, pesados y procesados para el análisis morfométrico. Los grupos trtados con fluoxetina presentaron disminución del tamaño y peso testiculares, en comparación con el grupo control día 21. Los resultados demuestran que la manipulación del sistema serotoninérgico con fluoxetina durante el período crítico del desarrollo testicular, altera la población de células de Sertoli y todos los parámetros testiculares relacionados con este tipo celular.

PALABRAS CLAVE: Fluoxetina; Desarrollo testicular; Células de Sertoli; Ratas Wistar.

\section{REFERENCES}

Abercrombie, M. Estimation of nuclear populations from microtome sections. Anat. Rec., 94:238-48, 1946.

Aguilar, R.; Antón, F.; Bellido, C.; Aguillar, E. \& Gaytan, F. Testicular serotonin is related to mast cells but not to Leydig cells in the rat. J. Endocrinol., 146:15-21, 1995.

Amann, R. P. \& Almquist, J. O. Reproductive capacity of dairy bulls. VIII. Direct and indirect measurement of testicular sperm production. J. Dairy Sci., 45:774-81, 1962.

Ansorge, M. S.; Zhou, M.; Lira, A; Hen, R. \& Gingrich, J. A. Early-life blockade of the 5-HT transporter alters emotional behavior in adult mice. Science, 306(5697):879-81, 2004.

Attal, J. \& Courot, M. Développement testiculaire et établissement de la spermatogénèse chez le taureau. Ann. Biol. Anim. Bioch. Biophys., 3:219-41, 1963.

Balon, R. Fluoxetine and sexual dysfunction. JAMA, 273:1489, 1995.
Bansal-Rajbanshi, M. \& Mathur, M. Testicular morphology and cell proliferation kinetics of immature germ cells and Sertoli cells in suckling undernourished rats. Cell Tissue Kinet., 18 (2):183-91, 1985.

Baumann, P. Pharmacology and pharmacokinetics of Citalopram and other SSRIs. Int. Clin. Psychopharmacol, 1:5-11, 1996.

Caccia, S.; Cappi, M.; Fracasso, C. \& Garattini, S. Influence of dose and rout of administration on the kinetics of fluoxetine and its metabolite norfluoxetine in the rat. Phychopharmacology, 100(4):509-14, 1990.

Campos, M. B.; Vitale, M. L.; Calandra, R. S. \& Chiochio, S. R. Serotoninergic innervations of the rat testis. $J$. Reprod. Fertil., 88:475-9, 1990.

Cantor, J. M.; Binik, Y. M. \& Pfaus, J. G. Chronic fluoxetine inhibits sexual behavior in the male rat: reversal with oxytocin. Psychopharmacology, $144: 355-62,1999$ 
SILVA, J. V. A.; LINS, A. M. J. A. A.; AMORIM, J. A. A.; PINTO, C. F.; DEIRó, T. B. J.; OLIVEIRA, J. R. M.; PEIXOTO, C. A. \& MANHÃES-DE-CASTRO, R. Neonatal administration of fluoxetine decreased final sertoli cell number in Wistar rats. Int. J. Morphol., 26(1):51-62, 2008.

Cooke, P. S. Role of thyroid hormone in Sertoli cell mitogenesis and differentiation. Molecular Andrology, 17:177-89, 1995.

Das, T. K.; Mazunder, R,. \& Biswas, N. M. Spermatogenesis in rat: effect of L-tryptophan loading. Andrologia, 14:242-9, 1982.

Das, T. K.; Mazunder, R. \& Biswas, N. M. Effect of intraventricular injection of 5,6-dihydroxytryptamine on spermatogenesis and plasma testosterone levels in rat. J. Endocrinol., 106:395-400, 1985.

Das,T. K.; Mazunder, R. \& Biswas, N. M. Further evidence for an inhibitory effect of L-trryptophan loading on testicular functions of rat. Andrologia, 18:618-23, 1986.

Deiró, T. C. B. J.; Manhães de Castro, R.; Cabral Filho, J. E.; Souza, S. L.; Freitas, S.; Ferreira, L. M. P.; Guedes, R. C. A.; Câmara, C. R. V. \& Barros, K. M. F. T. Neonatal administration of citalopram delays somatic maturation in rats. Braz. J. Med. Bio. Res., 37:1503-9, 2004.

Dorst, V. J. \& Sajonski, H. Morphometrische untersuchunhen am tubulussystem des schweinehodens während der postnatalen entwicklug. Monotsh. Ver. Med., 29:650-2, 1974.

Dufau, M. L.; Tijanero, J. C. \& Fabbri, A. Corticotropinreleasing factor: an anti-reproductive hormone of the testis. Faseb Journal, 7:299-307, 1993.

Ellis, L. C.; Jaussi, A. W.; Baptista, M. W. \& Urry, R. L. Correlation of age changes in monoamine oxidase activity and androgen synthesis by rat testicular minced and teased preparation in vitro. Endocrinology, 90:16108,1972 .

França, L. R. Neonatal hypothyroidism: a model system for increasing testis size and sperm production. Rev. Bras. de Reprodução Animal, 19:141-51, 1995.

França, L. R. \& Cardoso, F. M. Duration of spermatogenesis and sperm transit time through the epididymis in the piau boar. Tiss. Cell, 30(5):573-82, 1998.

França, L. R. \& Russel, L. D. The testis of domestic mammals. In : Male reproduction; a multidisciplinary overview. Madrid, Churchill Communications Europe, 1998. pp 198-219.

França, R. L.; Silva, Jr. V. A.; Chiarini-Garcia, H.; Garcia, S. K. \& Debeljuk, L. Cell proliferation and hormonal changes during postnatal development of the testis in the pig. Biol. Reprod., 63:1629-36, 2000.

Frank, J. L. W.; Hendricks, S. E. \& Olson, C. H. Multiple ejaculations and chronic fluoxetine effects on male rat copulatory behavior. Pharmacol. Biochem. Behav., 66:337-42, 2000.

Frungieri, M. B.; Gonzalez-Calvar, S. I.; Rubio, M.; Ozu, M.; Lustig, L. \& Calandra, R. S. Serotonin in golden hamster testes: testicular levels, immunolocalization and role during sexual development and photoperiodic regression-recrudescence transition. Neuroendocrinology, 69:299-308, 1999.

Gandarias, J. M.; Echevarria, E.; Acebes, I.; Abecia, L. C.; Casis, O. \& Casis, L. Effects of fluoxetine administration on um-opiod receptor immune-staining in the rat forebrain. Brain Res., 817:36-240, 1999.

Gilmore, D. P. The involvement of the endogenous opioids in the regulation of reproduction. Biogenic Amines, 14(4):331-54, 1995.

Hedger, M. P.; Khatab, S.; Gonzales, G. \& De Kretser, D. M. Acute and shot-term action of serotonin administration on the pituitary-testicular axis in the adult rat. Reprod. Fertil. Dev., 7:1101-9, 1995.

Heikkinen, T.; Ekblad, U.; Palo, P. \& Laine, K. Pharmacokinetics of fluoxetine andnorfluoxetine in pregnancy and lactation. Clin. Pharmacol. Ther., 73:330-7, 2003.

Hess, R. A.; Cooke, P. S.; Bunick, D. \& Kirby, J. D. Adult testicular enlargement induced by neonatal hypothyroidism is accompanied by increased Sertoli and germ cell numbers. Endocrinology, 132:2607-13, 1993.

Hochereu De Reviers, M. T. \& Lincoln, G. A. Seasonal variation in the histology of the testis of the red deer, Cervus elaphus. J. Reprod. Fertil., 54:209-13, 1978.

Holden, C. Prozac treatment of newborn mice raises anxiety. Science, 306(5697):792, 2004.

Kalla, N. R. Demonstration of direct effect of serotonin on rat Leydig cell. Andrologia, 11:259-62, 1979.

Kops, S. K., Theoharides, T. C.; Cronin, C. T.; Kashgarian, M. G. \& Askenase, P. W. Ultra structural characteristics of rat peritoneal mast cells undergoing differential release of serotonin without histamine and without degralulation. Cell. Tissue Res., 262:415-24, 1990. 
SILVA, J. V. A.; LINS, A. M. J. A. A.; AMORIM, J. A. A.; PINTO, C. F.; DEIRÓ, T. B. J.; OLIVEIRA, J. R. M.; PEIXOTO, C. A. \& MANHÃES-DE-CASTRO, R. Neonatal administration of fluoxetine decreased final sertoli cell number in Wistar rats. Int. J. Morphol., 26(1):51-62, 2008.

Labbate, L. A.; Grimes, J. B. \& Arana, G. W. Serotonin reuptake antidepressant effects on sexual function in patients with anxiety disorders. Biol. Psychiatry, 43:9047, 1998.

Liu, J. \& Lauder, J. M. Serotonin promotes region-specific glial influences on cultures serotonin and dopamine neurons. Glia, 5:306-17, 1992.

Macguirk, J. \& Siloverstone, T. The effect of 5-HT re-uptake inhibitor fluoxetine on food intake and body weight in healthy male subject. Int. J. Obes., 14:361-72, 1990.

Matuszcyk, J.V.; Larsson, K. \& Eriksson, E. The selective serotonin reuptake inhibitor fluoxetine reduces sexual motivation in male rats. Pharmac. Biochem. Behav., 60: 527-32, 1998.

Mendes da Silva, C.; Souza, S. L.; Barreto Medeiros, J. M.; Freitas-Silva, S. R.; Antunes, D. E. C.; Cunha, A. D. U.; Ribas, V. R.; França, M. F. S.; Nogueira, M. I. \& Manhães de Castro, R. Neonatal treatment with fluoxetine reduces depressive behavior induced by forced swim in adult rats. Arq. Neuropsquiatr., 60(4):928-31, 2002.

Morris, P. L.; Vale, W. W. \& Bardin, W. b-endorphin regulation of $\mathrm{FSH}$-stimulated inhibin production is a component of a short loop system in testis. Biochem. Biophys. Res. Commun., 148:1513-9, 1987.

Morrison, J. L.; Riggs, K. W. \& Rurak, D. W. Fluoxetine during pregnancy: impact on fetal development. Reprod. Fertil. Dev., 17(6):641-50, 2005.

Naumenko, E. V. \& Shishkina, G. T. Role of serotonin in feedback control of hypothalamic-pituitary-testicular complex in male rat. Neuroendocrinology, 26:359-366, 1978.

Nowakowska, E.; Kus, K. \& Chodera-Otuszewska, R. Behavioural effects of two antidepressants with opposite action mechanisms. Biol. Psychiatry., 42(1S):297, 1997.

Ohman, R.; Hagg, S.; Carleborg, L. \& Spigset, O. Excretion of paroxetine into breast milk. Clin. Phychiatry, 60(8):519-23, 1999.

Orth, J. M. \& Boehm, R. Endorphin suppresses FSHstimulated proliferation of isolated neonatal Sertoli cells by a pertussis toxin-sensitive mechanism. Anat. Rec., 226:320-7, 1990.

Orth, J. M. FSH-induced Sertoli cell proliferation in the developing rat is modified by beta-endorphin produced in the testis. Endocrinology, 119(4):1876-8, 1986.

Orth, J. M. Proliferation of Sertoli cells in fetal and postnatal rats: a quantitative autoradiographic study. Anat. Rec., 203:485-92, 1982.

Orth, J. M. Cell biology of testicular development in fetus and neonate. In: Desjardins, C. \& Ewing, L. L. (eds), Cell and Molecular Biology of the Testis, 1st ed. New York, Oxford University Press, 1993. pp 3-42.

Palén, K.; Thörneby, L. \& Emanuelsson, H. Effects of serotonin antagonists on chick embryogenesis. Wilhelm Roux's. Arch. Dev. Biol., 187:89-103, 1979.

Sanders-Bush, E. \& Mayer, S. E. 5-Hydroxytryptamine (Serotonin): Recptor agonists and antagonists. In:The pharmacological basis of therapeutics. New York, MacGraw-Hill, 2001. pp 269-90.

Simansky, K. J. Serotoninergic control of the organization of feeding and satiety. Behav. Brain Res., 73:37-42, 1996.

Spigset, O.; Carieborg, L.; Ohman, R. \& Norstrom, A. Excretion of citalopram in breast milk. Br. J. Clin. Pharmacol., 449(3):295- 8, 1997.

Syed, V.; Gomez, E. \& Hecht, N. B. Messenger ribonucleic acids encoding a serotonin receptor and a novel gene are induced in Sertoli cells by a secreted factor(s) from male rat meiotic germ cells. Endocrinology, 140(12):5754-60, 1999.

Syed, V. \& Hecht, N. B. Selective loss of Sertoli and germ cell function leads to a disruption in Sertoli cell-germ communication during aging in the Brown Norway rat. Biol. Reprod., 64:107-12, 2001.

Tinajero, J. C.; Fabbri, A. \& Dufau, L. Serotonergic inhibition of rat Leydig cell function by propanolol. Endocrinology, 133:257-64, 1993.

Toornvliet, A. C.; Pijl, H.; Hopman, E.; Elte-de Wever, B. M. \& Meinders, A. E. Serotoninergic drug-induced weight loss in carbohydrate craving obese patients. Int. J. Obes. Relat. Metab. Disord., 20(10):917-20, 1996.

Urry, R. L. \& Dougherty, M. S. Inhibition of rat spermatogenesis and seminiferous tubule growth after short-term and long-term administration of a monoamine oxidase inhibitor. Fertil. Steril., 26:2328,1975 . 
SILVA, J. V. A.; LINS, A. M. J. A. A.; AMORIM, J. A. A.; PINTO, C. F.; DEIRÓ, T. B. J.; OLIVEIRA, J. R. M.; PEIXOTO, C. A. \& MANHÃES-DE-CASTRO, R. Neonatal administration of fluoxetine decreased final sertoli cell number in Wistar rats. Int. J. Morphol., 26(1):51-62, 2008.

Van Haaster, L. H.; De Jong, F. H.; Docter, R. \& De Rooij, D. G. High neonatal triiodothyronine levels reduce the period of Sertoli cell proliferation and accelerate tubular lumen formation in the rat testis, and increased serum inhibin levels. Endocrinology, 133:755-60, 1993.

Vega Matuszcyk, J. V.; Larsson, K. \& Eriksson, E. The selective serotonin reuptake inhibitor fluoxetine reduced sexual motivation in male rats. Pharmacol. Biochem. Behav., 60:527-32, 1998.

Verbeuren, T. J. Syntesis, storage, release, and metabolism of 5-hydroxytryptamine. In: Fozard, J. R. (ed). The peripheral action of 5-hydroxytriptamine. Oxford, Oxford University Press, 1989. p 25.

Waldinger, M. D. \& Olivier, B. Selective serotonin reuptake inhibitor-induced sexual dysfunction: clinical and research considerations. Int. Clin. Psychopharmacol., 12 (6):S27-33, 1998.

Whitaker-Azmitia, P. M. Role of serotonin and other neurotransmitter receptors in brain development: basis for developmental pharmacology. Pharmal. Rev., 43(2):553-61, 1991.

Wong, D. T.; Reid, R. L. \& Threlke, P. G. Supression of food intake in rats by fluoxetine: comparision of enantiomers and effects of serotonin antagonists. Pharmacol. Biochem. Behav., 31:475-9, 1988.

Yan, W.; Wilson, C. C. \& Haring, J. H. 5-HT1A receptors mediate the neurotrophic effect of serotonin on developing dentate granule cells. Dev. Brain Res., 98(2):185-90, 1997.

Zagen, A.; Nakash, R.; Roth-Deri, I.; Overstreet, D. H. \& Yadid, G. Impaired release of b-endorfina in response to serotonin in a rat model of depression. Neuroscience, 11(3): 339-93, 2002.

Zhengwei, Y.; Wreford, N. G. \& Kretser, D. M. Quantitative study of spermatogenesis in developing rat testis. Biol. Reprod., 43:629-35, 1990.
Correpondence to:

Dr. Valdemiro Amaro da Silva Junior

Departamento de Morfologia e Fisiologia Animal

Universidade Federal Rural de Pernambuco

CEP 52171-900

Recife- PE

BRASIL

\section{Email: vajunior@ufrpe.br}

Received: 12-08-2007

Accepted: 15-11-2007 